Ethiopian Journal of Environmental Studies \& Management 10(1): 55 - 63, 2017.

ISSN:1998-0507

doi: http://dx.doi.org/10.4314/ejesm.v10i1.6

Submitted: October 07, 2016

Accepted: January 20, 2017

\title{
AN EVALUATION OF ADEQUACY OF WATER POLICY STIPULATION IN ENSURING WATER SECURITY IN THE CONTEXT OF CLIMATE CHANGE
}

\section{CHITAMBI, $M$.}

Dag Hammarskjold Institute for Peace and Conflict Studies, Copperbelt University School of Graduate Studies, P.O. Box 21692, Kitwe, Zambia

Email: musengechitambi@gmail.com

\begin{abstract}
The aim of the study was to establish how responsive the Water Policy (2010) is to ensure water security in the context of climate change. The objectives of the study were to establish if the water policy addresses water security and to determine whether the water policy addresses challenges in the climate change context and to examine national initiatives that address climate change response. Recognizing the broadness of the concept of water scarcity, the study limited the scope to establishing the relationship between water policy and water security in the changing climate. The study focused on water institutions mandated to deliver on water policies rather than the quantitative aspects of water scarcity. The study revealed that although there is some attention to water security in the water policy there is lack of commitment in terms of how climate change will be mitigated to ensure water security. The findings of the study also indicate that the water sector is managed among various ministries and this has resulted in overlapping competencies in ensuring water security with climate change impact. This indicates that there is need to have policy that has clear strategy in terms of a roadmap for mitigation of climate change impact on water security. In view of the findings of this study, it is recommended that the government should put in place a clear climate change policy to adequately address climate change and its impact on the water sector.
\end{abstract}

Key Words: Climate change, Water security, Water policy, Water scarcity

\section{Introduction}

Water is an essential resource with lifesustaining ability i.e., it is indispensable for humans as it is a source of drinking water, a basis for hygiene and food supply. Economic development and industrial activities are also water dependant, (UNESCO, 2006).However; water withdrawals have increased six-fold since the 1900's which is twice the rate of population growth, (UNESCO, 2006).

The relative abundance of water and the fact that available fresh water supplies are 60 times larger than the levels of withdrawals for economic consumption masks water scarcity in Zambia, (World Bank, 2009). The total renewable water resources of Zambia amount to about $105 \mathrm{~km} 3$ per year of which about $80 \mathrm{~km} 3$ is 
produced internally. The renewable water resource per capita is estimated at about $8,700 \mathrm{~m} 3$ per year well above the average for the sub-Saharan Africa $(7,000 \mathrm{~m} 3$ per person per year) and the global average $(8,210 \mathrm{~m} 3$ per person per year). Zambia lies entirely within two of Africa's great river basins. Seventy-two per cent of Zambian territory falls within the Zambezi basin including the upper reaches of the main stem of the Zambezi River as well as all the catchments for the Kafue and Luangwa rivers, (World Bank, 2009). The remaining twenty-eight per cent of the country falls within the upper reaches of the Congo River basin, including the Luapula, Chambeshi and Tanganika catchments. Available water in any area depends on how much surface and groundwater is available in rivers, lakes, reservoirs, and aquifers.

Water scarcity is defined as a situation where insufficient water resources are available to satisfy long term average requirements. It refers to long term water imbalances, combining low water availability with a level of water demand exceeding the natural recharge, (EUCommission, 2007). This is manifested in the imbalance between water availability and demand and the lack of water availability and demand and the lack of timely and reliable access to water resources timely and reliable access to water resources for different economic and social groups. The risk of water scarcity and the opportunity to overcome it depends not only upon the physical endowments of water but also the institutional, technical and infrastructure capacity of a country to manage water successfully to the satisfaction of all stakeholders supported by the availability of financial resources to address water related issues. Per the categorization undertaken by the
International Water Management Institution (2007) Zambia can be classified as a country of economic water scarcity. While water resources are abundant they are not effectively applied to the country's development goals due to the limiting institutional, technical, and financial capacity of the country (World Bank, 2009). This is called second order scarcity which is defined as a lack of social and potential adaptive capacity to manage water successfully to the satisfaction of all stakeholders (DFID, 2007). Therefore, good governance and accountability and the consideration of the interests of all stakeholders through appropriate and effective legal regimes through institutions properly planed, operated, and maintained infrastructure and capacity development (UN-Water, 2011). In other words, all dimensions of an extended security concept (food security, economic security, and human security at large) depend on water. This crucial importance of water in every part of the world makes it an essential component of international, national, and local security (Boge, 2006).

\section{Description of Study Area}

Lusaka is the largest city in the country of Zambia covering an area of 423 square kilometres. Lusaka province is in the central part of Zambia and shares provincial boundaries with Southern province in the South, Central province in the North and Eastern province in the East. Its land mass is 21,896 square kilometres. Lusaka district which is the capital city of Zambia is situated in Lusaka province. It lies at between longitude 10-28 degrees east of the prime meridian and between latitudes 15-30 degrees South of the equator. The surface area of the district is 360 square kilometres (Gauff JBF, 2011).

The climate of Lusaka is characterised by four seasons namely winter running 
from June to August, the pre-rainy season from September to October, the rainy season from November to March and post rainy season from April to May. The average temperature is about $20^{\circ} \mathrm{C}$ with a mean minimum of $15^{\circ} \mathrm{C}$ and a mean maximum of $26^{\circ} \mathrm{C}$. Rainfall is heaviest in December with an average of $220 \mathrm{~mm}$ for the month. Lusaka enjoys a relatively humidity rise, significantly over the monthly average of 62.8 percent to about
84 percent in January (Agyemang et al., 1997).

The dominant vegetation type found in the Lusaka area is the open deciduous woodland known locally as 'miombo' accounting for about 80 percent of the forested area and providing valuable commercial species, while in the south and west the munga, a savannah woodland dominates (Agyemang et al., 1997).

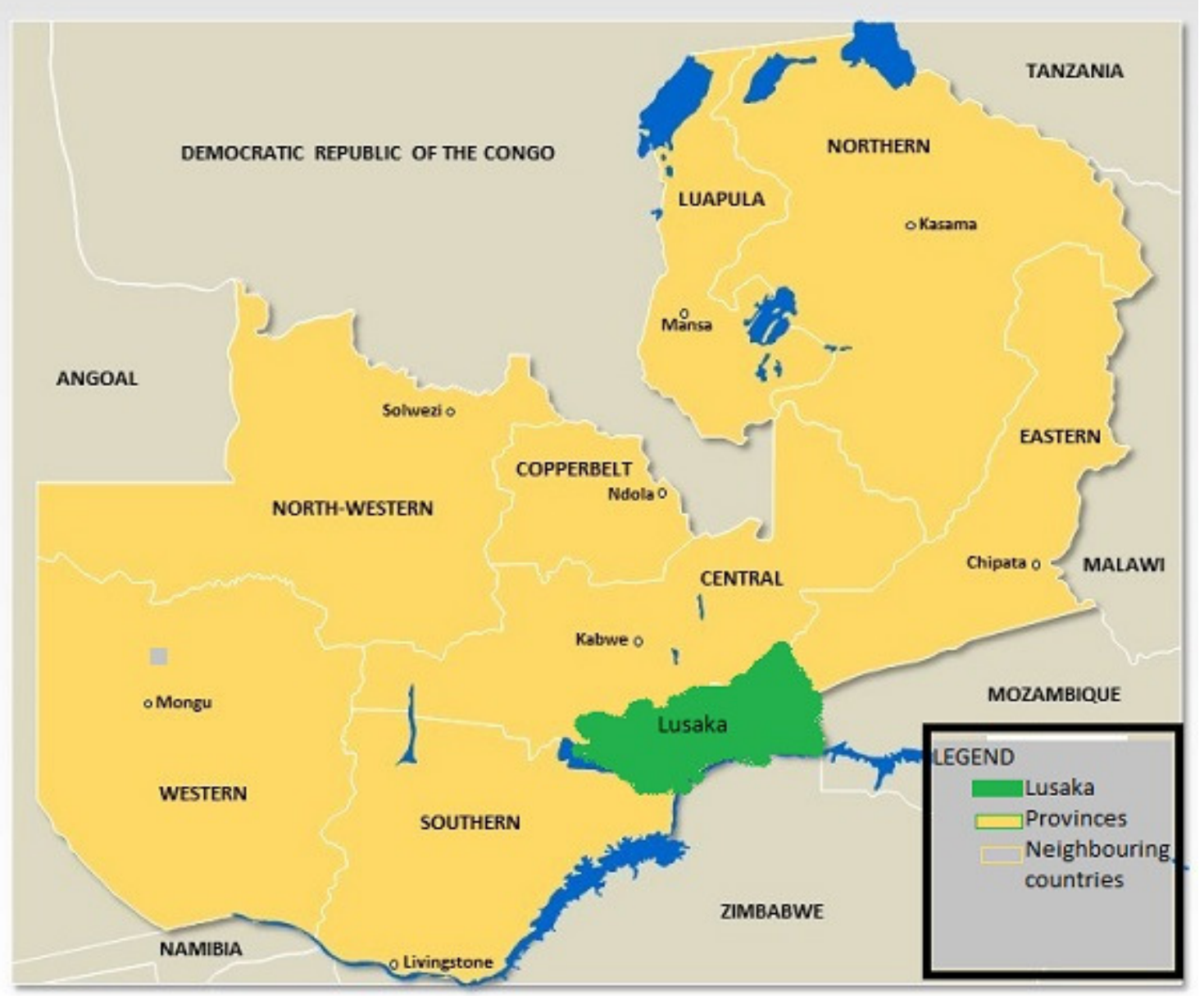

Figure 1: Map showing the location of the study area

\section{Methodology}

\section{Sample Selection}

A total sample of seven Stakeholder Institutions in climate change and water policy implementation was selected using Purposive sampling. The Institutions were all from Lusaka because that is where Government Ministries and most Private sector headquarters are located. The basis for the selection was the Institutions mandate in water policy, water security/management and Climate change. 
The sampled institutions and ministries included NWASCO, Ministry of Energy and Water Development, Water aid, Department on Climate change under the Ministry of Lands, Natural resources, and Environment. The Water Affairs department, Climate change secretariat under the Ministry of Finance, the Zambia Meteorological Department under the Ministry of Transport and Communication. Semi structured interviews were conducted with key informants from the institutions to supplement policy analysis. The interviews covered concerns within the Water Policy (2010) in relation to water security and climate change impact specifically how the policy has outlined the water security concept in the context of vulnerabilities presented by climate change. Data was mainly acquired mainly from document/policy review from the selected Institutions, to seek more understanding on the subject prior documentation such as institutional records, progress reports and Institutional libraries mandated with water resource management were used to establish a deeper perspective on water policy and water security in the context of climate change. The literature reviewed was primarily Journals, published work, but in a few cases unpublished work such as draft policies.

\section{Data Analysis}

Thematic analysis was used to identify and describe both implicit and explicit words or phrases and ideas that were grouped as themes such as water security, water resources management and climate change. A theme as defined by Braun and Clark (2006) 'captures something important about the data in relation to the research question and represent some level of patterned response or meaning within the data set'. Documents were analysed using a coding process which involved using descriptive and evaluative coding which helped lead to grouping of important categories within my data. Saldana (2009) defines a code in qualitative research as 'most often a word or short phrase that symbolically assigns a summative, salient, essence-capturing and /or evocative attribute for a portion of language based or visual data. I made notes along the margins of my paper documents and interview transcripts of these categories which helped to capture emerging themes or concepts.

\section{Results and Discussion}

\section{Water Policy and Water Security}

The water policy 2010 reference to water security aspect is provided through the Environmental Protection and Pollution Control Act of 1990 and the Environmental Council of Zambia (ECZ). These programmes and projects implemented with close collaboration of the line ministries have contributed to the protection and conservation of the environment including water resources. Zambia has only built five large dams and has approximately one thousand seven hundred small dams despite the existing potential for the development of such facilities (FAO,2010). The state of affairs is attributed to limited funding to the sector.

The lack of adequate information on boreholes and dams negatively impacts on strategic planning for water resources and affects efforts to regulate groundwater development.

Table 2 below shows some of the laws that deal with water usage, pollution control and conservation as part of natural resources management. They are complementary to the Water policy objectives for water resources management and development which enhance collaboration and cooperation among the key stakeholders in Zambia. 
Table 1: Complementing Acts to the Water Policy

\begin{tabular}{|c|c|}
\hline Enabling Act & Purpose \\
\hline $\begin{array}{l}\text { Constitution of Zambia } 1991 \text { (as amended in } \\
\text { 2006) }\end{array}$ & $\begin{array}{l}\text { The Bill of Rights and the directive principles of } \\
\text { state policy establishes the framework within } \\
\text { which the regulation and allocation of water can } \\
\text { take place }\end{array}$ \\
\hline $\begin{array}{l}\text { National Heritage Conservation Act Cap.173 } \\
\text { (enacted in 1961) }\end{array}$ & $\begin{array}{l}\text { This Act provides for the conservation of, inter } \\
\text { alia, ancient, cultural, and natural heritage and } \\
\text { objects of aesthetic, historical and scientific } \\
\text { interest. }\end{array}$ \\
\hline Lands Act Cap.184 (enacted in 1995) & $\begin{array}{l}\text { In Zambia,all land is vested in the President, } \\
\text { under section } 3 \text { of the Lands Act,who holds it in } \\
\text { perpetuity for and on behalf of the people of } \\
\text { Zambia. }\end{array}$ \\
\hline $\begin{array}{l}\text { Environmental Protection and Pollution Control } \\
\text { Act, Cap 204(enacted in 1990) }\end{array}$ & $\begin{array}{l}\text { This Act provides for the protection of the } \\
\text { environment and the control of pollution }\end{array}$ \\
\hline $\begin{array}{l}\text { Local Government Act Cap } 281 \text { (enacted in } \\
\text { 1991) }\end{array}$ & $\begin{array}{l}\text { The local government Act in the second } \\
\text { schedule lists the functions of a council which } \\
\text { state as follows to provide and maintain supplies } \\
\text { of water and for that purpose to establish and } \\
\text { maintain water works and water mains. }\end{array}$ \\
\hline $\begin{array}{l}\text { The Public Health Act, Cap 295(enacted in } \\
\text { 1930) }\end{array}$ & $\begin{array}{l}\text { Responsible for monitoring sanitation drinking } \\
\text { water and general sanitary supervision }\end{array}$ \\
\hline $\begin{array}{l}\text { The Mines and Minerals Development Act, No.7 } \\
\text { of } 2008\end{array}$ & $\begin{array}{l}\text { Provide environmental protection during } \\
\text { prospecting and mining and abandonment of } \\
\text { mines }\end{array}$ \\
\hline $\begin{array}{l}\text { The Zambia development Agency Act, No.11 of } \\
2006\end{array}$ & $\begin{array}{l}\text { Fosters economic growth and development by } \\
\text { promoting trade and investment in Zambia } \\
\text { through an efficient and coordinated private } \\
\text { sector led economic development strategy }\end{array}$ \\
\hline $\begin{array}{l}\text { The Water Supply and Sanitation Act, No } 28 \text { of } \\
1997\end{array}$ & $\begin{array}{l}\text { Regulates water supply and sanitation service } \\
\text { providers }\end{array}$ \\
\hline $\begin{array}{l}\text { The Energy Regulation Act Cap. } 436 \text { (enacted in } \\
\text { 1995) }\end{array}$ & $\begin{array}{l}\text { Established the energy regulation board and } \\
\text { defines its functions and powers, provides } \\
\text { licenses of undertakings for production of energy }\end{array}$ \\
\hline
\end{tabular}

The water resource management objectives in the water policy are to ensure that water resources are preserved and maintained at acceptable quality standards. To achieve the objectives for water resources management the following measures must be put in place, the need to contribute to the minimization of the impact of water related disasters such as droughts and floods through the provision of early warning systems and put in place emergency management systems. The water shortage areas should be declared and establish institutions for the management of shared water courses in collaboration with national institutions to ensure that Zambia's interests are protected. Early warning systems in collaboration with other relevant institutions are required; also there is a need to promote preventable measures through community education and 
awareness. Collaboration with regional and international bodies in dealing with emergency situations is also highlighted.

Water for Environment measures in the water policy is to increase public awareness on the conservation and protection of water resources and the environment. There is also a need to prevent and control pollution of ground and surface water, maintain and protect the natural quality of water resources in the country. Water for National Heritage measures in the water policy is to conserve and manage water resources in collaboration with the institution responsible for national heritage. There is need to encourage the practice and expression of folklore and customs related to water resources among indigenous people.

\section{Water Policy and Climate Change}

The water policy reference to climate change is to put in place measures to be implemented to mitigate climate change impact. There is need of conducting public awareness campaigns to ensure that the public is enlightened on climate change issues, including mitigation and adaptation measures. In addition, the policy has in place measures of assessing and monitoring the potential impact of climate change on ecosystems especially woodlands, forests, and wetlands. An investment in irrigation systems is required and the supply of clean and safe water to communities to prevent water borne diseases that come with floods/droughts. Developing and promoting alternative energy sources to fuel, wood, and technologies to reduce the use of fuel wood and woodlands, forests, and wetlands, strengthening the existing national climate and meteorological databases and monitoring networks.
Water resources are intractably linked with climate, so the prospect of global climate change has serious implications for water resources and regional development. Though Zambia has abundant water resources does not imply that it faces no climate change challenges related to the water sector. These challenges have a major influence on the country's socioeconomic development. The poor distribution of surface water in many parts of the country especially the southern province results in local shortages. Access to sufficient and clean water is critical to the general development of the country, as it contributes to wealth creation, poverty reduction and disease prevention. The effect of climate change has made droughts and floods to become recurrent. The Zambia Meteorological Department (ZMD) has summarised the climate trends in Zambia over the past decades as having an increase in the frequency of extreme events such as floods and droughts. There has been a tendency of delayed onset and earlier cessation of rainfall resulting in shorter seasons and intense rainfall. An increase in temperature in both cool and warm seasons has also been dictated.

The study findings reveal that adequate policy is vital in the management of water resources. The decentralisation on environmental policy result in increased local capacity in mature democracies such as Zambia, where local capacity may be constrained by lack of financial and technical resources and entrenched political processes (Assetto et al., 2003). Therefore, for water management to be effective and politically feasible it must balance politics, economics, environmental aspects, and national security (Allen, 2002).

There is low adaptive capacity for responsible institutions under the Climate 
change facilitation unit (CCFU). The lack of decentralisation of most institutions under the CCFU has made government institutions inadequate in supporting access to much needed natural resources by communities' dependant on resources for survival and adaptation to climate variability. The non-integration of crosscutting impacts of climate change limits decision makers understanding of climate change impacts and their implications for national economics. This has undermined the political importance of prioritization and resource mobilisation for creating institutions with adaptive capacity to climate change. The absence of appropriate policy framework in the implementation of adaptation response has affected the resource mobilisation for building institutions with resilience to support communities to respond to their vulnerabilities. Adaptive capacity is dependent on policies and strategies to respond to the needs and support the resilience of the most vulnerable groups in society. Huitema and Merijerink (2010) are from the policy science approach which illustrates the role of policy entrepreneur's, key change agents that create or take advantage of opportunities to shift the paradigm. The policy sciences approach focuses on how new ideas are developed due to focusing events or shocks that galvanize willingness to adopt new policies.

The Zambian government water policy (2010) findings show that the policies major priorities include decentralizing decision making processes reach the lower levels of stakeholders. The policy also strives for the promotion of active community and stakeholder participation in the design, implementation and management of water resources related programs and projects. The policy also emphases that there should be a promotion of regional cooperation in water resources management and improve areas of research, data collection and information sharing. The policy draws inspiration from the principle of integrated water resource management with stakeholder participation and decentralisation. Although Zambia may have sufficient water during the rainy season the high meteorological variability coupled with inadequate infrastructure storage delivery and management are resulting in water scarcity in certain instances. The challenges affecting the country are namely, lack of decentralisation and sustainable structure's that are accessible and consider the participation of stakeholders/communities who are the most affected with climate change. There is poor resources management in terms of water resources this can be shown in the minimal budget allocation for the water sector. Regulation and enforcement of legislation is another challenge the policy is in place but coordination across various ministries is not uniform. Inadequate investment in water storage infrastructure because of recurring droughts and floods is also another challenge. The policy does not prioritise the roadmap to ensure water security in the context of climate change impacts it mainly focuses on the institutional arrangement of water resources management.

Water management in Zambia has been managed on sectorial basis. This has resulted in limited approaches to the development of a comprehensive strategy for water resources management. The water sector is characterised with many different organisation and authorities ranging from policy, legal formulation and implementation to service provision and consumption. Water resources ownership 
is vested in the republican president of Zambia. Water resources administration is spread across various ministries, departments, and agencies. The ministry of Energy and Water Development with the Department of Water Affairs (DWA) and the Water Board have the overall responsibility for water resources management and development in Zambia. The ministry of Agriculture and Cooperatives (MACO) is responsible for monitoring the use of water for cropping activities. The ministry of Livestock and Fisheries is responsible for monitoring the use of water for fishing, farming, and livestock watering. The ministry of Local Government and Housing (MLGH) is the lead ministry in water supply and sanitation and is also responsible for policy development in this field for the physical planning of water supply and for sanitation services and resource mobilization. The ministry of Lands, Environment and Natural Resources is mandated with the protection of water resources. The ministry of Health oversees setting standards and monitoring the quality of drinking water. The Office of the Vice President coordinates disaster management. The ministry of Transport and Communication provides meteorological services and is responsible for inland waterways while the ministry of Mines is responsible for dewatering in mines.

As a result of overlapping competencies, the inter-ministerial competition for control of important water resources affects the coordinated planning and implementation of policies such as water security in relation to climate change that are important to development of the water sector. Strategies in the water sector have been characterised by unclear institutional arrangements, which often conflict or overlap with each other.
Though the policymakers reference to its focus on the relationship of water and environmental protection, the efforts are directed to the prime responsibility of management and allocation of water resources. Strategies to deal with climate change are not clear.

\section{Perceptions on Water Policy, Water Security and Climate Change}

Most of the Institutions were of the view that the water policy (2010) has not adequately addressed climate change impact on the water security and provide a clear strategy of how to ensure water security. One Institution was of the view that the Water policy should be revised as in its current form does not adequately address issues of Climate change impact on water security.

National Initiatives and Strategies on Climate Change Response

The reduced emissions from Deforestation and Degradation (REDD) is a pilot strategy under the UN and Zambia is among the countries selected to participate in the strategy. This strategy also aims to build collaborative approaches to land and forest management. The Forestry Department is the leading agency undertaking the REDD project with support from UNFAO, UNEP and UNDP. Zambia is signatory to the Kyoto protocol of the United Nations Framework on Climate change. The Ministry of Environment and Natural Resource is the lead ministry on environment issues and coordinates implementation of the protocol and Clean Development Mechanism project in Zambia (CDM). The ministry with other stakeholders have established the Designated National Authority (DNA) to facilitate implementation of $\mathrm{CDM}$ projects. These projects are said to contribute to global reduction in 
greenhouse gases emissions and promote sustainable development in Zambia.

\section{Conclusion}

The study revealed that although there is some attention to water security and climate change in the water policy, there is lack of commitment in terms of written policy on how climate change is being managed. There is neither a clear strategy nor is there set benchmarks as to how progress is to be monitored. The study also revealed that the various water management ministries and institutions had overlapping competencies and were not addressing water security in the context of climate change. Response to climate change in terms of water security should be fully reflected in the mindset of various ministries and institutions in the water sector. The aim is to develop strategies that can mitigate impacts of climate change on the water resources and ensure water security.

\section{Acknowledgment}

I would like to acknowledge Dr. J. Bwalya and Mr. O. Tembo for their valuable assistance on this paper.

\section{References}

Agyemang, O.A., Chirwa, B. and Muya, M. (1997). An Environmental Profile of the Greater Lusaka area.

Allen, J.A. (2002). The middle east water question, hydro politics, and the global economy. London and New York

Assetto, V.J., Hajba, E. and Mumme, S.P. (2003).

Democratization, decentralisation, and local environmental policy capacity:
Hungary and Mexico. Social Science Journal, 40:249-268.

Boge, V. (2006). Water Governance in Southern Africa Co-operation and Conflict prevention in trans boundary river basins. Boom International Centre for Conversion. Brief 33, Bonn: Germany

DFID (2007). Technical report: Second order water scarcity in Southern Africa

European Union Commission (2007). Water scarcity and droughts, second interim reports

FAO (2010). Draft Zambia National Investment brief

Gauff JBF Ingenieure Report (2011). Lusaka Drainage Project in Lusaka area.

Huitema, D. and Meijerink, S. (2010). Realising water transitions. The role of policy entrepreneurs in water policy change. Ecology and Society, 15(2): 26.

International Water Management Institute, (2007). Water for life water for food. A comprehensive assessment of water management in Agriculture. A summary report

Saldana, J. (2009). Participate Observation. New York: Holt, Pinehart and Winston.

UN-Water (2011). Analytical brief. Water security

UNESCO-WWAP (2006).Water development report 2.

World Bank (2009). IPCC technical paper Zambia, managing water for sustainable growth and poverty reduction. A country water resources assistance strategy for Zambia 